\title{
İrritabl Bağırsak Sendromuna Güncel Bakış
}

\author{
Irritable Bowel Syndrome: Up to Date
}

\author{
Birsen Yılmaz ${ }^{1}$, Gamze Akbulut ${ }^{2}$
}

Geliş tarihi/Received: 09.06.2017 • Kabul tarihi/Accepted: 19.11.2018

\section{ÖZET}

İrritabl bağırsak sendromu (İBS), gastrointestinal sistem hastalıkları arasında en sık rastlanan kronik işlevsel bir hastalıktır. Toplumun geniş bir kısmını etkilemesinin yanı sıra bazı hastalar semptomlarını normal kabul edip herhangi bir sağlık kuruluşuna başvurmamaktadır. Etiyolojisi tam olarak anlaşılamamıştır. Hastaların semptomlarına göre tedavi seçilse de genellikle yaşam tarzında değişiklikler (özellikle beslenmeye yönelik), farmakolojik tedavi ve psikolojik destek tedavinin temelini oluşturmaktadır. İrritabl bağırsak sendromlu hastalar için yararlı olabileceği düşünülen güncel diyet yaklaşımları: fermente oligo-, di- ve mono-sakkaritler ile poliollerden düşük (FODMAP) bir diyet, gaz yapıcı besinlerin, laktozun ve glutenin diyetten çıkarılması veya sınırlandırılması ve hastaların İBS alt sınıflarına göre posa miktarının arttırılması ya da azaltılması şeklindedir. İrritabl bağırsak sendromunun etiyolojisinin anlaşılabilmesi ve yeni tedavi yöntemlerinin geliştirilebilmesi için daha fazla araştırmaya gereksinme vardır.

Anahtar kelimeler: İrritabl bağtrsak sendromu, beslenme, FODMAP, gastrointestinal sistem

\section{ABSTRACT}

Irritable bowel syndrome (IBS) is the most common chronic functional disease of the gastrointestinal system. Although the disease affects a large part of the population, some patients do not refer any health care services since they accept their symptoms as normal. Etiology of the disease has not been fully understood. Although the treatment of IBS is usually decided based on the symptoms of the patients, the most common therapeutic approaches for IBS include changes in lifestyle (especially nutrition), pharmacological and psychological treatments. The current diet approach, which is thought to be useful for IBS patients might include the following measures: a diet low in fermentable oligo-, di- and monosaccharides and polyols (FODMAPs), limitation or exclusion of gas-producing foods and/or lactose and gluten increasing/decreasing the amount of fiber according to IBS subclasses. Further research is needed to understand the etiology of IBS and to develop new treatment approaches.

Keywords: Irritable bowel syndrome, nutrition, FODMAP, gastrointestinal system

\section{GİRIŞ}

İrritabl bağırsak sendromu (İB), klinik olarak organik bir patoloji olmaksızın, bağırsak alışkanlıklarında değişiklik (konstipasyon/ diyare), karın ağrısı, dispeptik yakınmalar (gaz,

1. İletişim/Correspondence: Gazi Üniversitesi, Sağlık Bilimleri Fakültesi, Beslenme ve Diyetetik Bölümü, Beşevler, Ankara, Türkiye - E-posta: dytbirsen@gmail.com (D) https://orcid.org/0000-0002-4866-2818 şişkinlik, geğirme) gibi alt ve üst gastrointestinal semptomlar ile karakterize etiyolojisi tam olarak bilinmeyen kronik bir işlevsel bağırsak hastalığıdır (1).

2. Gazi Üniversitesi, Sağlık Bilimleri Fakültesi, Beslenme ve Diyetetik Bölümü, Beşevler, Ankara, Türkiye

(1) https://orcid.org/0000-0003-0197-1573 
İrritabl bağırsak sendromuna özgü bir tanı testinin bulunmaması ve tanıyı doğrulayan yapısal ya da biyokimyasal belirteçlerin günümüzde halen mevcut olmaması nedeniyle, benzer durumlara yol açan diğer organik hastalıklar ekarte edilerek ve semptomlar iyi bir şekilde değerlendirilerek tanı konulur. Ancak semptomlar da yeteri kadar spesifik değildir. Hastalığın tanısında belirli tanı kriterlerinin kullanılması, diğer hastalıkları ekarte etmek için tanısal testlerin uygulama gereksinimini azaltmakta ve zaman kazandırmaktadır. Hastalığa özgü ilk olarak 1978 yılında tanı kriterleri geliştirilmiştir (2). Manning ve arkadaşları (2), dört semptomun (abdominal distansiyon, bağırsak hareketi ile ağrı, ağrı başlangıcı ile daha sık ve yumuşak defekasyon) İBS'de organik hastalıklara göre daha fazla olduğunu bildirmiştir (3). Manning kriterlerinin, İBS'yi organik gastrointestinal hastalıklardan ayırt etmedeki sensitivitesinin \%58, spesifitesinin \%74 olduğu gösterilmiştir (4). Manning kriterleri baz alınarak 1990 yılında Roma I kriterleri oluşturulmuştur. Roma I kriterlerini araştıran çok sayıda makale olmamakla birlikte, bir çalışmada sensitivitesi $\% 65$, spesifitesi $\% 100$ olarak bildirilmiştir (5). Roma I kriterlerini daha yararl bir hale getirebilmek amacıyla, 1999 yllında yapılan konsensus toplantısında Roma II kriterleri geliştirilmiştir (6). Amerikan Gastroenteroloji Derneği’nin öncülüğü ile 23 Mayıs 2006 tarihinde yapılan toplantıda, Roma III kriterleri geliştirilmiştir. Son olarak 2016 yllında yayınlanan son tanı kriterlerine göre (Roma IV) İBS tanısı konulmaktadır $(7,8)$. Roma IV kriterlerine göre, tanıdan en az 6 ay önce başlamış olmak şartıyla son 3 ay içinde, haftada en az 1 gün tekrarlayan abdominal ağrı ile beraber aşağıdakilerden en az 2 veya daha fazlasının varlığı ile İBS tanısı konulabilmektedir:

1. Defekasyonla ilişkili olması (hafiflemesi),

2. Defekasyon sıklığının değişmesiyle beraber olması,

3. Feçesin görünümünde değişiklikle birlikte olması.

Bu derleme makalede irritabl bağırsak sendromunun tıbbi beslenme tedavisine ilişkin bilimsel literatür verilerinin incelenmesi ve tartışılması amaçlanmıştır.

\section{İrritabl Bağırsak Sendromunun Patofizyolojisi}

İrritabl bağırsak sendromunun patofizyolojisi tam olarak bilinmemekle birlikte birçok etmenin etkisi olabileceği bildirilmektedir (9). Motilite bozukluğu, visseral aşırı duyarlılık, intestinal inflamasyon ve enfeksiyonlar, bakteriyel aşırı çoğalma, santral sinir sistemi modülasyonu ve besin intoleransı, psikososyal etmenler ve genetik, patogenetik etmenlerin başında gelmektedir (5).

Bu bilgilerin yanı sıra, diyetin de İBS patofizyolojisinde rolü olabileceği bildirilmektedir. Beslenme alışkanlıkları ile birlikte stres ve menstrual siklus, İBS'yi alevlendiren/tetikleyen en yaygin etmenlerdir (9). Diyet bileşenlerinin İBS'deki rolü konusunda çok fazla çalışma olmasa da İBS'li hastaların belirli besinlere karşı alerji/aşırı duyarlılı̆̆ı olduğu ve bu durumun bağışıklık aktivasyonu yoluyla belirtilerin şiddetini arttırabileceği ifade edilmektedir. Ayrıca, fruktoz, laktoz, sorbitol ve diğer şeker alkolleri gibi karbonhidrat türleri intoleransa neden olabilmektedir (10). Diyet etmenleri ve İBS arasındaki potansiyel etkiler Şekil 1'de özetlenmiştir (9).

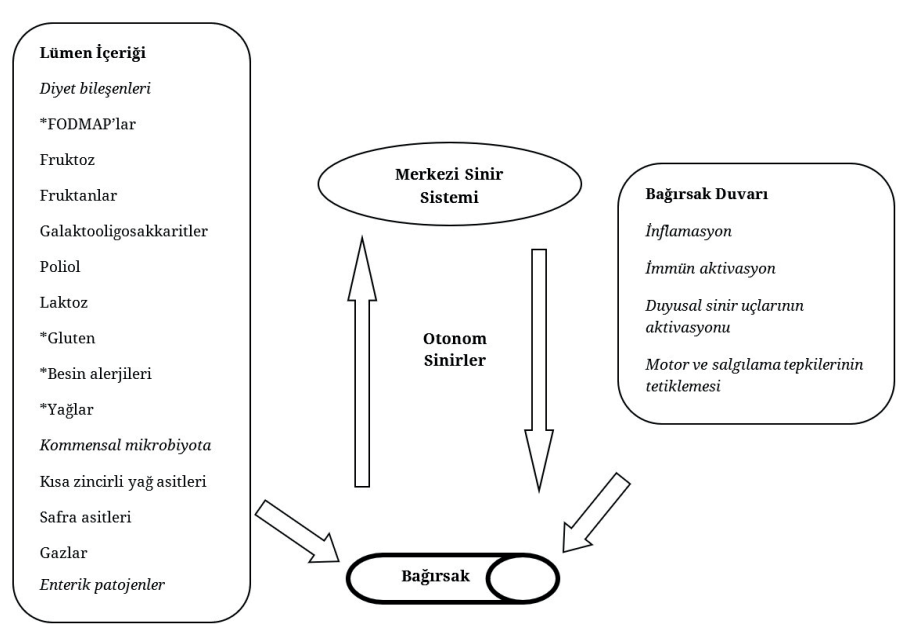

Şekil 1. Diyet etmenleri ve İBS arasındaki potansiyel etkileşimler (9)

\section{İrritabl Bağırsak Sendromunun Epidemiyolojisi}

İrritabl bağırsak sendromu, bölgeler ve ülkeler arası, prevalans, semptom ve cinsiyet dağılımı açısından farklılıklar göstermektedir. Ancak yapılan epidemiyolojik çalışmalarda, çalışma ortamı, yöntemi 
ve kullanılan tanı kriterlerinin birbirinden farklı olması nedeniyle, uluslararası karşılaştırmalar yapılamamaktadır (11-14). İrritabl bağırsak sendromu sıklıkla genç yetişkin bireylerde görülmekle beraber, her yaşta karşılaşılabilir. Birinci basamak sağlık kuruluşlarında doktora başvurma nedenlerinden birisi olan İBS aynı zamanda gastroenteroloji polikliniklerinde de sıklıkla karşılaşılan bir hastalıktır. İrritabl bağırsak sendromunun temelde üç alt tipi bulunmaktadır (konstipasyon baskın tip, diyare baskın tip ve değişen diyare/konstipasyon tip İBS). Görülme sıklığı en yüksek olan tip, konstipasyon baskın İBS’dir. Hastalara yönelik veriler incelendiğinde hastalığın kadınlarda görülme sıklığının erkeklerden daha yüksek olduğu bildirilmektedir. İrritabl bağırsak sendromlu hastaların çoğunluğunun yaşları 20-40 arasındadır (12-14).

Dünya genelinde \%5-20 oranında İBS görüldüğü bildirilmektedir (15). Batı toplumlarında prevalans \%8-23 oranında olup bunun \%60-70'ini kadınlar oluşturur. En düşük prevalans oranına sahip ülkenin Singapur (\%2.3), en yüksek prevalans oranına sahip ülkenin ise \%30 ile Nijerya olduğu bildirilmektedir (16-18). Asya ülkelerinde, popülasyonun \%1-10’unda İBS ile uyumlu semptomlar mevcuttur (18).

Türkiye verileri tam olarak bilinmemekle birlikte, Roma II kriterleri kullanılarak yapılan bir çalışmada, İBS prevalansının \%19 olduğu ve kadınlarda daha sık görüldüğü bildirilmiştir (13). Roma II kriterleri dikkate alınarak yapılan çalışmaların sonucuna göre ülkemizdeki İBS prevalansı \%6.3-27 arasında değişmektedir (3,12-14).

\section{Besin İntoleransı, Besin Alerjisi ve İrritabl Bağırsak Sendromu}

Besin intoleransı (alerjik olmayan besin duyarlılığı), besinlere karşı immünolojik olmayan enzimatik (laktoz intoleransı), farmakolojik (besinlerdeki doğal vazoaktif aminlerin doğrudan etkisi) ve tanımlanamayan reaksiyonlar grubunu kapsar. Besin intoleransında kolona geçen maddeler, lümene doğru sıvı akışına ve dolayısıyla bağırsak düzeninin değişmesine neden olmaktadır. Besin alerjisi (besin hipersensitivitesi) ise besin alımı sonrası oluşan herhangi bir anormal immünolojik reaksiyonu kapsamaktadır. $\mathrm{Bu}$ reaksiyonların çoğu spesifik immünoglobulin E aracılığıyla ortaya çıkmaktadır (19).

Besin intoleransı, günümüzde dünya genelinde yaygın olarak görülen bir durumdur. Genel popülasyonun \%15-20'sini etkilediği bildirilmektedir (20). Yapılan bir çalışmada besin intoleransının, İBS hastalarında da sıklıkla karşılaşılan bir durum olduğu (hastaların \%25-65'inde) ve semptomların genellikle besin alımı sonucu ortaya çıktığı belirtilmektedir. Ayrıca aynı çalışmada İBS hastalarının yaklaşık üçte biri abdominal semptomlarm bir nedeni olarak besinleri suçlamaktadır (21). Yemek yedikten sonra artış gösteren belirtiler, kolonun motor aktivitesindeki artmayla veya hipersensitiviteyle açıklanabilir. Genel olarak diyetle süt, yumurta ve buğday alımının semptomlarda artışla ilişkili olduğu gösterilmiştir (22).

Ülkemizde 90’lı yıllarda 4331 kişi üzerinde yapılan bir çalışmada, besin intoleransı prevalansı genel popülasyonda \%4.5 olarak saptanmıştır (23). Avustralya'da yapılan bir çalışmada İBS hastası olan ve olmayan kadınların diyetle enerji ve besin alımları karşılaştırılmıştır. Bireylerin enerji, yağ, protein ve posa alımlarının benzer olduğu, ancak İBS'li bireylerin rafine karbonhidrat alımlarının daha yüksek olduğu saptanmıştır (24).

Guo ve arkadaşlarının (25), 2012 yılında yapmış olduğu çalışmada, İBS hastalarının diyetlerinden spesifik immünoglobulin G (IgG) ilişkili besinler çıkartılmış ve hastalar 12 hafta boyunca izlenmiştir. Sağlıklı kontrol grubuna göre diyare baskın İBS’li hastalarda abdominal ağrl, distansiyon ve diyare gibi semptomlarda anlamlı azalmalar saptanmıştır. Zuo ve arkadaşlarının (26), çalışmasında ise IgG antikorları ve semptomların şiddeti arasında herhangi bir ilişki bulunmamıştır. İrritabl bağırsak sendromlu hastalar üzerinde 2004 yılında yapılan başka bir çalışmada IgG düzeyi yüksek çıkan besinler diyetten 
çıkarılmış ve hastalar 12 hafta boyunca izlenmiştir. Bu sürenin sonunda hastaların kolonik ve nonkolonik (anksiyete ve depresyon durumları, yaşam kalitesi vb.) semptomlarında anlamlı düzelmeler olduğu saptanmıştır. Hastalar uyguladıkları diyeti bıraktıktan sonra \%24’ünde semptomlarda tekrar artış olduğu bildirilmiştir (27).

Besin alerjisinin gerçek sıklığını belirlemek zor olmakla birlikte 14 İBS hastası, 15 işlevsel dispepsi ve 14 normal kolonik işlevi olan üç gruptan oluşan bireyler üzerinde yapılan bir çalışmada, besin alerjisi tanısında kullanılan testlerden biri olan deri prick testine pozitif yanıt İBS'li hastalarda anlamlı olarak yüksek bulunmuştur (28). İrritabl bağırsak sendromlu hastalarda besin alerjisi tanısı konulurken kullanılan altın standart "sorunlu görülen besini diyetten çıkarma” testleridir. Nanda ve arkadaşlarının (29) çalışmasında 200 hasta değerlendirilmiştir. Çalışmanın sonunda diyetten çıkarma uygulaması (süt ürünleri, tahıllar, turunçgiller, patates, çay, kahve, alkol ve gıda katkı maddeleri) ile hastalardaki pozitif yanıt oranı \%47.9 olarak saptanmıştır (29).
Çok net bir sonuç olmamakla birlikte bazı besinlere karşı İBS hastalarının semptomlarında artış olduğu gözlemlenmiştir. $\mathrm{Bu}$ besinler, süt, yumurta, balık, findık, su ürünleri ve buğdaydır $(29,30)$. Wahnschaffe ve arkadaşlarının (31), 102 İBS hastası üzerinde yürüttüğü bir çalışmada, hastaların \%35’inde çölyak hastalığının genetik belirteçleri pozitif bulunmuştur. $\mathrm{Bu}$ hastalara glutensiz diyet tedavisi uygulandığında iyileşmelerinde anlamlı bir farklılık saptanmıştır (30).

\section{İritabl Bağırsak Sendromu ve Tıbbi Beslenme Tedavisi}

İrritabl bağırsak sendromu mortalite riski düşük bir hastalık olsa da hastaların yaşam kalitesini ciddi derecede düşürmekte, depresyon ve anksiyete düzeylerini arttırmaktadır. Bu nedenle İBS tedavisi güvenli ve multidisipliner bir yaklaşım içerisinde yapılmalıdır. Ayrıca İBS çok yaygın görülen bir hastalık olduğundan hastalığın tanı ve tedavisine ayrılan süre ve maliyet de artmaktadır (21,31). İrritabl bağırsak sendromunun diyet tedavisine yönelik öneriler Tablo 1'de verilmiştir (31).

Tablo 1. İrritabl bağırsak sendromunun tıbbi beslenme tedavisine yönelik öneriler (31)

\begin{tabular}{|c|c|c|c|}
\hline Müdahale & Kanıt niteliği & Yarar/zarar & Önerinin gücü \\
\hline $\begin{array}{l}\text { 1.Semptomların olası nedenlerini belirlemek için dikkatli bir } \\
\text { beslenme öyküsü almak }\end{array}$ & Çok düşük & Net yarar & Nitelikli \\
\hline $\begin{array}{l}\text { 2.Diyetle posa alımını değerlendirmek ve önerilen miktara göre bir } \\
\text { azalma/artma durumunu göz önünde bulundurmak }\end{array}$ & Düşük & Net yarar & Nitelikli \\
\hline 3.Buğday kepeği veya laktozun diyetten çıkarılması & Düşük & Belirsiz & Nitelikli \\
\hline $\begin{array}{l}\text { 4.İntoleransı tanımlamak için sistematik diyet modifikasyonlarının } \\
\text { göz önünde bulundurulması }\end{array}$ & Düşük & Belirsiz & Nitelikli \\
\hline
\end{tabular}

Cozma-Petrut ve arkadaşları (32), güncel rehberler ve araştırmaları göz önünde bulundurarak İBS’ye özgü bir besin piramidi geliştirmiştir. Piramidin temelini düzenli fiziksel aktivite ve sağlıklı hidrasyon oluşturmaktadır. Piramidin diğer basamaklarında ise günlük tüketilmesi önerilen besin gruplarının porsiyon ölçüleri (tahıl ve ürünleri 6 porsiyon/gün, sebzeler 3-5 porsiyon/gün, meyveler 2-3 porsiyon/gün, et, balık, yumurta kurubaklagiller ve sert kabuklu meyveler 2-3 porsiyon/gün, süt ve süt ürünleri 2-3 porsiyon/gün) kanıt düzeylerine göre ifade edilmiştir (32).

\section{Posa}

Diyet posası, bitki hücre duvarını oluşturan nişasta olmayanpolisakkaritler,sindirilmeyenoligosakkaritler, lignin ve dirençli nişastadan oluşan bileşiklerdir. Diyet posasıyla ilgili çeşitli tanımlar bulunmakla birlikte genel olarak, besinlerin bir bileşeni olarak insan vücudunun sindiremediği veya kan dolaşımına emilimini yapamadığı kompleks karbonhidratlara verilen isim olarak tanımlanmaktadır. Posa, diğer karbonhidratlar gibi enerjiye dönüşemez ve kullanılmadan vücuttan atılır (33). 
Meyve ve sebzeler hem çözünen, hem çözünmeyen nişasta olmayan polisakkaritleri önemli miktarlarda içerirken, tahıllar (özellikle kepek) çözünmez posadan zengindir (33). İrritabl bağırsak sendromu hastalarının semptomlarını önlemek veya azaltmak için geleneksel diyet tedavisinde posadan zengin beslenme ön plana çlkmaktadır. Ancak insan çalışmalarında, yüksek ve düşük posa alan hastalar karşılaştırıldığında anlamlı bir değişiklik gözlenmemiştir. Bu nedenle posanın İBS'de olumlu etkileri olup olmadığı konusu hala tartışmalıdır (10). Yapılan bir meta analiz çalışmasının sonuçlarına göre, "pisilyum” gibi çözünen posa desteğinin İBS semptomları ve konstipasyonun hafifletilmesinde yararlı olabileceği, ancak kepek gibi besinlerde bulunan çözünmez posa ile plasebo arasında herhangi bir fark olmadığı, her ikisinin de semptomları alevlendirmediği bildirilmiştir (34). İkinci basamak tedavi hizmetlerinde ankete dayalı yapılan bir araştırmanın sonuçlarına göre tahıllarla alınan posanın vakaların yaklaşık \%55'inde semptomları kötüleştirdiği, yalnızca \%11'inde bir yararı olduğu rapor edilmiştir (35). İrritabl bağırsak sendromunda posanın etkisinin incelendiği bir sistematik derlemede, İBS'de posanın etkisinin değişken olduğu ve tüm posa türlerinin yararlı olmadığı ifade edilmiştir (36). Ayrıca posa alımının birden arttırılması semptomları kötüleştirebildiğinden, aşamalı olarak önerilerde bulunulmalıdır (36).

\section{Fermente Oligo-, Di- ve Monosakkaritler ve Poliol İçeriği Düşük Diyet}

Son yıllarda yapılan çalışmaların ışığında, bağırsak hastalıklarında uygulanan kısa zincirli, emilmeyen/emilim oranı düşük olan karbonhidratların sinırlandırıldığı fermente oligo-, di- ve monosakkaritler ile poliollerden düşük (FODMAP) bir diyetin hastalık semptomlarını (özellikle inflamatuvar bağırsak hastalığı ve İBS) azalttığı, bağırsakların motilitesini ve sekresyonunu değiştirdiği bildirilmektedir (37,38). Bin dokuz yüz seksen ve 1990'lı yıllarda yapılan gözlemsel kohort çalışmalarında, FODMAP diyetinin semptomatik şikâyetleri azalttığı saptanmıştır (37). Güncel çalışmalar ise bu hipotezi doğrular niteliktedir. Fermente oligo-, di-ve monosakkaritler ile poliollerden düşük diyet teriminin tarihsel sürecine bakıldığında, özellikle 2005 yılında bir grup Avustralyalı araştırmacı tarafından kullanıldığı ve bilimsel literatürde sıkça bahsedildiği görülmektedir (37).

Düşük FODMAP içerikli diyet, fermente oligosakkaritler, disakkaritler, monosakkaritler ve poliollerin diyette azaltılması prensibine dayanmaktadır. Fermente oligo-, di- ve monosakkaritler ile poliollerden düşük diyet, bütün kısa zincirli karbonhidratları içermektedir. Bu ögelerin zayıf düzeyde absorbe edilip bağırsakta hızlı fermente olduğu bilindiğinden semptomları arttırdığı düşünülmektedir (39). Yüksek FODMAP içeren diyetlerle karşılaştırıldığında, düşük FODMAP içeren diyetlerin Gİs semptomlarını azalttığı gösterilmiştir (10). Bunun yanı sira düşük FODMAP içeren diyetlerin hastaların yaşam kalitesini arttırdığı, intestinal mikrobiyotayı ve gastrointestinal endokrin hücrelerini olumlu yönde etkilediği bildirilmiştir (4042).

Başlıca FODMAP bileşenleri, diyetsel kaynakları ve buna alternatif olarak tüketilebilecek besinler Tablo 2'de gösterilmiştir $(37,43)$.

\section{Probiyotik ve Prebiyotiklerin Etkisi}

Probiyotikler, konakçının bağırsak florasındaki dengeyi sağlayarak, sağlığını olumlu yönde etkileyen canlı mikroorganizmalar olarak tanımlanmaktadır. Prebiyotikler ise, ince bağırsak enzimlerince parçalanamayan doğal karbonhidratlar olup Laktobasillus ve Bifidobakteri gibi belirli probiyotik bakterilerin çoğalmasını uyarırlar (44).

Probiyotiklerin İBS üzerindeki etkisini araştırmak için yapılan bir çalışmada L. plantarum MF 1298'in İBS tedavisi ve semptomları üzerindeki etkileri incelenmiş ve bu türün İBS’nin semptomları üzerinde herhangi bir olumlu etkisine rastlanmamıştır (45). Semptomların iyileşme süresi plasebo grubunda $L$. plantarum grubuna göre anlamlı olarak daha yüksek çıkmıştır. 


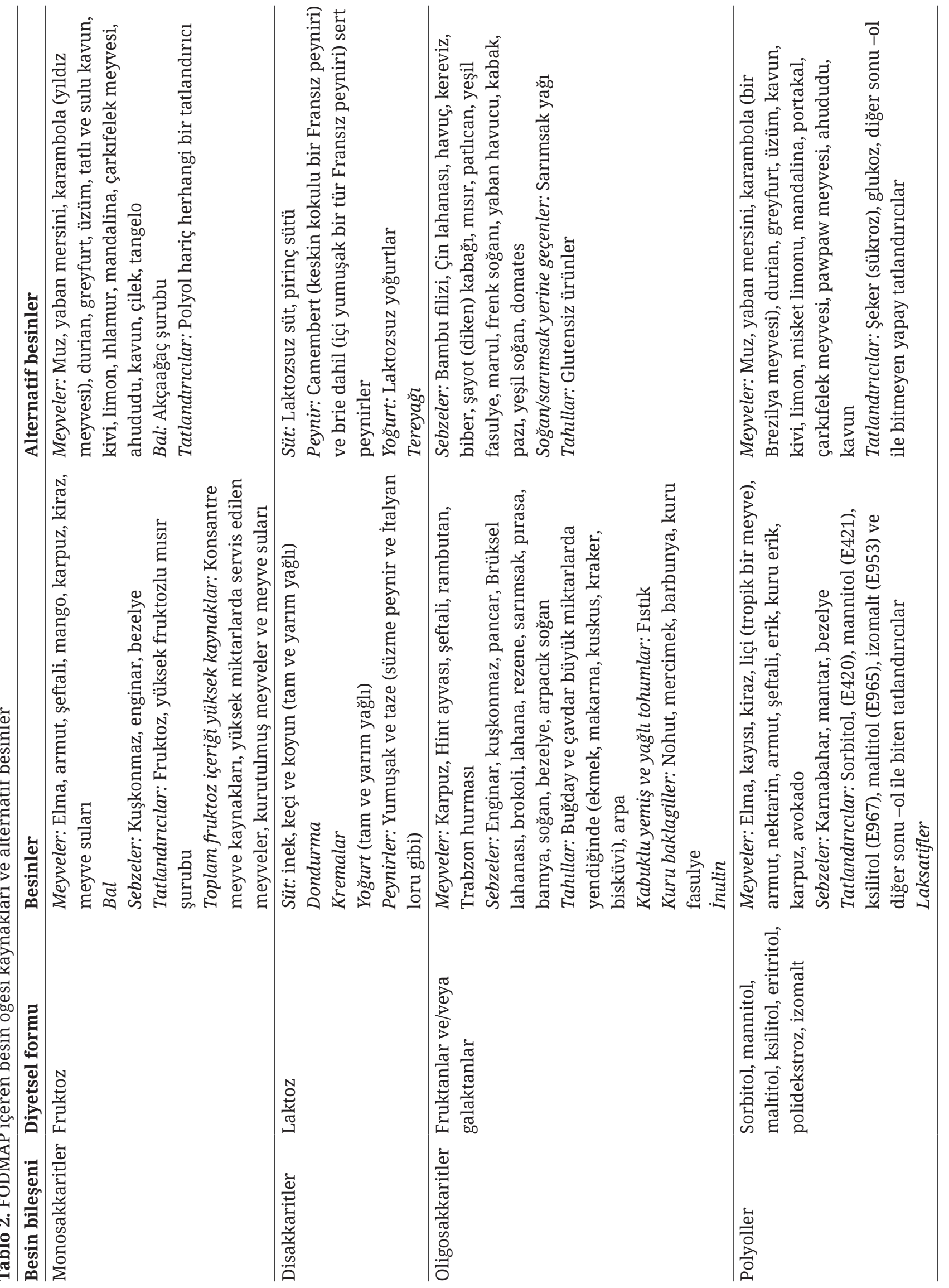


Başka bir çalışmada, fermente süt ürünlerinde bulunan bir probiyotik olan Bifidobacterium animalis DM 173010 türünün İBS hastalarında 6 aylık kullanımı sonucunda yaşam kalitesini arttırdığı, haftada üçten az dışkılama sıklığı olan bireylerde dışkılama sıklığını arttırdığı saptanmıştır (46). Plasebonun etkisini değerlendirmek amacıyla yapılan bir çalışmada İBS'li hastalara probiyotikli ve probiyotiksiz süt ürünleri (yoğurt) verilmiştir. Dört hafta süren bu çalışmanın sonucunda çalışma grubu ve kontrol grubu arasında semptomlar açısından anlamlı bir fark saptanamamıştır (47).

İnülin, fruktooligosakkaritler, galaktooligosakkaritler, soyaoligosakkaritleri, laktosukroz, laktuloz, izomaltooligosakkaritler, glikooligosakkaritler, ksilooligosakkaritler, platinoz, gentiooligosakkaritler gibi bileşikler prebiyotik özellik taşırlar. Prebiyotiklerin kolon mikroflorası, immün işlevler, mineral biyoyararlanımı, lipit metabolizması üzerinde yararlı ve kolon karsinogenezini önleyici etkileri vardır. Oligosakkaritler, hücre yüzey reseptör analoğu gibi hareket eder ve patojen mikroorganizmaları kendisine bağlayıp dışkı ile atılmasını sağlar (48).

Hem prebiyotik hem probiyotik içeren bir ürün kullanılarak yapılan 4 hafta süren bir çalışmada, hastaların yaşam kalitesi (SF-36) skorları kontrol grubuna göre daha yüksek bulunurken, distansiyon ve gaz şikayetlerinde de azalma saptanmıştır (49).

Son yllarda İBS tedavisinde probiyotik ve prebiyotiklerin kullanımı üzerinde sıklıkla durulmaktadır. Probiyotik kullanımı bir bütün olarak bazı olumlu etkiler sağlamasına karşılık, tür, suş veya kombinasyonlar ile doz ve süre konusunda henüz net veriler yoktur (32). Yapılan çalışmalardan alınan sonuçlar birbirinden farklı olmakla birlikte kullanılan ürünlerin İBS'de orta derecede etkiye sahip olduğu bildirilmiştir. $\mathrm{Bu}$ etkinin pro- ve prebiyotiklerin antiinflamatuvar ve immün düzenleyici etkilerinden kaynaklı olduğu düşünülmektedir (50).

\section{SONUÇ VE ÖNERİLER}

Son ylllarda İBS tedavisinde diyetin rolü üzerinde çok durulmaktadır. Özellikle düşük FODMAP diyeti konusunda çalışmalar artış eğilimindedir. Ayrıca glutensiz diyetler ve probiyotik kullanımı gibi yaklaşımlar da söz konusu olmakla birlikte, literatürde henüz kanitlar yetersizdir. Bu nedenle İBS hastalarının diyetinde bilinçsiz kısıtlamalar/ eklemeler yapmadan, bir diyetisyen kontrolünde tıbbi beslenme tedavisi almaları önerilmektedir. Literatürde farklı diyet modelleri yer alsa da uzun dönem etkinliklerinin doğrulanması için geniş çaplı ve iyi tasarlanmış randomize kontrollü çalışmalara gerek vardir.

Çıkar çatışması - Conflict of interest: Yazarlar çıkar çatışması olmadığını beyan ederler. - The authors declare that they have no conflict of interest.

\section{KAYNAKLAR}

1. Baykan AR, Kasap E, Gerçeker E, Yüceyar H. İrritabl barsak sendromu ve genetik. Güncel Gastroenteroloji 2012;16(1):53-5.

2. Manning AP, Thompson WG, Heaton KW, Morris AF. Towards positive diagnosis of the irritable bowel. BMJ 1978;2(6138):653-4.

3. Tan MN, Ylldırım E, Guldal D. Aile hekimliği pratiğinde sık görülen bir hastalık: irritabl bağırsak sendromu. TJFMPC 2014;8(3):75-85.

4. Talley NJ, Phillips SF, Melton LJ, Mulvihill C, Wiltgen C, Zinsmeister AR. Diagnostic value of the Manning criteria in irritable bowel syndrome. Gut 1990;31(1):77-81.

5. Gülşen M. İrritabl bağırsak sendromu. Güncel Gastroenteroloji 2007;11(2):98-121.

6. Thompson WG, Longstreth G, Drossman DA. Rome II: The functional gastrointestinal disorders. In: Drossman DA, Corazziari E, Talley NJ, editors. Functional bowel disorders. 2nd ed. McLean, VA: Degnon Associates, 2000. p. 355.

7. Drossman DA. The functional gastrointestinal disorders and the Rome III process. Gastroenterology 2006;130(5):1377-90.

8. Kaya M, Kaçmaz H. Roma IV kriterlerine göre fonksiyonel barsak hastalıklarının yeniden değerlendirilmesi. Güncel Gastroenteroloji 2016;20(4):393-407. 
9. Hayes PA, Fraher MH, Quigley EM. Irritable bowel syndrome: the role of food in pathogenesis and management. J Gastroenterol Hepatol (NY) 2014;10(3):164-74.

10. Lied GA, Lillestol K, Lind R, Valeur J, Morken MH, Vaali $\mathrm{K}$, et al. Perceived food hypersensitivity: a review of 10 years of interdisciplinary research at a reference center. Scand J Gastroenterol 2011;46(10):1169-78.

11. Quigley EM, Abdel-Hamid H, Barbara G, Bhatia SJ, Boeckxstaens G, De Giorgio R, et al. A global perspective on irritable bowel syndrome: a consensus statement of the World Gastroenterology Organisation Summit Task Force on irritable bowel syndrome. J Clin Gastroenterol 2012;46(5):356-66.

12. Şimşek İ, Şengül B. İrritabl barsak sendromu. Aktüel Tıp Dergisi 2004;9:60-4.

13. Karaman N, Türkay C, Yönem O. Irritable bowel syndrome prevalance in city center of Sivas. Turk J Gastroenterol 2003;14:128-31.

14. Çelebi S, Açık Y, Deveci SE, Bahçelioğlu IH, Ayar A, Demir A, et al. Epidemiological features of irritable bowel syndrome in a Turkish urban society. J Gastroenterol Hepatol 2004;19(7):738-43.

15. Ford AC, Vandvik PO. Irritable bowel syndrome: dietary interventions. BMJ Clin Evid 2015;7(410):1-13.

16. Talley NJ, Zinsmeister AR, Van Dyke C, Melton LJ. Epidemiology of colonic symptoms and the irritable bowel syndrome. Gastroenterology 1991;101(4):927-34.

17. Drossman DA, Li Z, Andruzzi E, Temple RD, Talley NJ, Thompson WG, et al. U.S. householder survey of functional gastrointestinal disorders. Prevalence, sociodemography, and health impact. Dig Dis Sci 1993;38(9):1569-80.

18. Kumano H, Kaiya H, Yoshiuchi K, Yamanaka G, Sasaki T, Kuboki T. Comorbidity of irritable bowel syndrome, panic disorder, and agoraphobia in a Japanese representative sample. Am J Gastroenterol 2004;99(2):370-6.

19. Sampson HA. Sleisenger Fordtran's Gastrointestinaland Liver Disease. In: Feldman M., Scharschmidt BF, Sleisenger MH, editors. Food allergies. WB: Saunders Co. Philadelphia; 1998. p. 1688-95.

20. Akbulut G, Tevfikoğlu Aleycan L, Küçükkatırcı S, Urtaoğlu S. Besin Alerjisi, Besin İntoleransı Durumlarında Beslenme ve Test Diyetleri. Akbulut G, editör. Tıbbi Beslenme Tedavisinde Günel Uygulamalar I. Ankara: Ankara Nobel Tıp Kitabevleri; 2015. s. 27.

21. Simren M, Mansson A, Langkilde AM, Svedlund J, Abrahamsson H, Bengtsson U, et al. Food-related gastrointestinal symptoms in the irritable bowel syndrome. Digestion 2001;63:108-15.

22. Sünger O. İrritabl bağırsak sendromlu hastalarda fibromiyalji sendromu prevalansı. Uzmanlık tezi, Başkent Üniversitesi, Ankara; 2011.

23. Kalyoncu AF, Stalenheim G. Survey on the allergic status in a Turkish population in Sweden. Allergol Immunopathol (Madr) 1993;21(1):11-4.

24. Jareth M, Heitkemper MM, Bond EF. Comparison of diet composition in women with and without functional bowel disorder. Gastroenterol Nurs 1994;16:253-8.

25. Guo H, Jiang T, Wang J, Chang Y, Zhang W. The value of eliminating foods according to food-specific immunoglobulin G antibodies in irritable bowel syndrome with diarrhoea. J Int Med Res 2012;40(1):20410.

26. Zuo XL, Li YQ, Li WJ, Guo YT, Lu XF, Li JM, et al. Alterations of food antigen-specific serum immunoglobulins $\mathrm{G}$ and $\mathrm{E}$ antibodies in patients with irritable bowel syndrome and functional dyspepsia. Clin Exp Allergy 2007;37(6):823-30.

27. Atkinson W, Sheldon TA, Shaath N, Whorwell PJ. Food elimination based on IgG antibodies in irritable bowel syndrome: a randomised controlled trial. Gut 2004;53(10):1459-64.

28. Soares RLS, Figueiredo HN, Maneschy CP, Rocha VRS, Santos JM. Correlation between symptoms of the irritable bowel syndrome and the response to the food extract skin prick test. Braz J Med Biol Res 2004;37:65962.

29. Nanda R, James R, Smith H, Dudley CR, Jewell DP. Food intolerance and the irritable bowel syndrome. Gut 1989;30:1099-104.

30. Wahnschaffe U, Ullrich R, Riecken EO, Schulzke JD. Celiac disease-like abnormalities in a subgroup of patients with irritable bowel syndrome. Gastroenterology 2001;121(6):1329-38.

31. Spiller R, Aziz Q, Creed F, Emmanuel A, Houghton L, Hungin P, et al. Guidelines on the irritable bowel syndrome: mechanisms and practical management. Gut 2007;56(12):1770-98.

32. Cozma-Petruţ A, Loghin F, Miere D, Dumitraşcu DL. Diet in irritable bowel syndrome: What to recommend, not what to forbid to patients!. World J Gastroenterol 2017;23(21):3771-83.

33. Samur G, Mercanlıgil SM. Diyet Posası ve Beslenme. Ankara: Klasmat Matbaacılık; 2008. s. 7.

34. Ford AC, Talley NJ, Spiegel BM, Foxx-Orenstein AE, Schiller L, Quigley EM, et al. Effect of fibre, antispasmodics, and peppermint oil in the treatment of 
irritable bowel syndrome: systematic review and metaanalysis. BMJ 2008;337:a2313.

35. Francis CY, Whorwell PJ. Bran and irritable bowel syndrome: time for reappraisal. Lancet 1994;344(8914):39-40.

36. El-Salhy M, Otterasen Ystad S, Mazzawi T, Gundersen D. Dietary fiber in irritable bowel syndrome (Review). Int J Mol Med 2017;40(3):607-13.

37. Mansueto P, Seidita A, D’Alcamo A, Carroccio A. Role of FODMAPs in patients with irritable bowel syndrome. Nutr Clin Pract 2015;30(5):665-82.

38. Gibson PR, Shepherd SJ. Personal view: food for thought-western lifestyle and susceptibility to Crohn's disease. The FODMAP hypothesis. Aliment Pharmacol Ther 2005;21(12):1399-409.

39. Çelebi F, Akbulut G. Barsak hastalıklarında güncel diyet yaklaşımı: Fermente oligo, di- ve mono-sakkaritler ve polyol (FODMAP) içeriği düşük diyet. Turkiye Klinikleri J Gastroenterohepatol 2014;21(2):43-52.

40. Halmos EP, Christophersen CT, Bird AR, Shepherd SJ, Gibson PR, Muir JG. Diets that differ in their FODMAP content alter the colonic luminal microenvironment. Gut 2015;64:93-100.

41. Mazzawi T, Hausken T, Gundersen D, El-Salhy M. Effect of dietary management on the gastric endocrine cells in patients with irritable bowel syndrome. Eur J Clin Nutr 2015;69(4):519-24.

42. Mazzawi T, Gundersen D, Hausken T, El-Salhy M. Increased gastric chromogranin A cell density following changes to diets of patients with irritable bowel syndrome. Mol Med Rep 2014;10(5):2322-6.
43. Gibson PR, Shepherd SJ. Evidence-based dietary management of functional gastrointestinal symptoms: The FODMAP approach. J Gastroenterol Hepatol 2010;25(2):252-8.

44. Bakır OB. Prebiyotik, probiyotik ve sinbiyotiklere genel bakış. Beslenme ve Diyet Dergisi 2012;40:178-82.

45. Ligaarden SC, Axelsson L, Naterstad K, Lydersen S, Farup PG. A candidate probiotic with unfavourable effects in subjects with irritable bowel syndrome: a randomised controlled trial. BMC Gastroenterology 2010;10:16.

46. Guyonnet D, Chassany O, Ducrotte P, Picard C, Mouret M, Mercier $\mathrm{CH}$, et al. Effect of a fermented milk containing Bifidobacterium animalis DN-173 010 on the healthrelated quality of life and symptoms in irritable bowel syndrome in adults in primary care: a multicentre, randomized, double-blind, controlled trial. Aliment Pharmacol Ther 2007;26(3):475-86.

47. Roberts LM, McCahon D, Holder R, Wilson S, Hobbs R. A randomised controlled trial of a probiotic 'functional food' in the management of irritable bowel syndrome. BMC Gastroenterology 2013;13(45):1-10.

48. Coşkun T. Pro-, pre- ve sinbiyotikler. Çocuk Sağlığı ve Hastalıkları Dergisi 2006;49:128-48.

49. Cappello C, Tremolaterra F, Pascariello A, Ciacci C, Iovino P. A randomised clinical trial (RCT) of a symbiotic mixture in patients with irritable bowel syndrome(IBS): effects on symptoms, colonic transit and quality of life. Int J Colorectal Dis 2013;28(3):349-58.

50. Sezer E, Saka M. İrritabl bağırsak sendromunun tedavisinde prebiyotik ve probiyotik kullanımı. Güncel Gastroenteroloji 2014;18(2):174-9. 